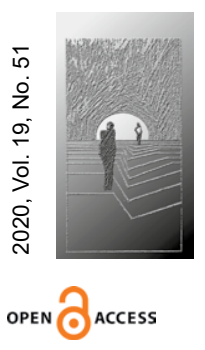

\title{
Uwarunkowania kształcenia zdalnego w rodzinie w dobie COVID-19
}

\section{STRESZCZENIE}

CEL NAUKOWY: Celem artykułu jest pokazanie uwarunkowań materialnych, kompetencyjnych i interpersonalnych edukacji zdalnej w Polsce w okresie od 12 marca do przełomu czerwca i lipca 2020 r.

PROBLEM I METODY BADAWCZE: Artykuł został napisany w ramach metodologii pedagogicznej przy wykorzystaniu metody jakościowej, która umożliwiła analizę doświadczenia konkretnych osób zaangażowanych w procesy edukacyjne w sytuacji pandemii COVID-19.

PROCES WYWODU: Artykuł pokazuje pozytywne i negatywne aspekty nauczania zdalnego z perspektywy członków rodzin uczestniczących w Polsce w nietypowym procesie dydaktycznym, wymuszonym przez pandemię groźnej choroby.

WYNIKI ANALIZY NAUKOWEJ: W artykule zostały pokazane materialne, kompetencyjne i interpersonalne uwarunkowania zdalnej edukacji.

WNIOSKI, INNOWACJE, REKOMENDACJE: Z badań wynika, że edukacja zdalna w warunkach pandemii wywarła znaczący wpływ na funkcjonowanie rodzin, co wymaga dalszych badań w sytuacji przedłużającego się stanu zagrożenia z powodu COVID-19.

$\rightarrow$ SŁOWA KLUCZOWE: COVID-19, PANDEMIA, RODZINA, PEDAGOGIKA RODZINY, EDUKACJA ZDALNA

ABSTRACT

Determinants of Distance Education in the Family in the COVID-19 Era

RESEARCH OBJECTIVE: The aim of the article is to show the material, competence and interpersonal conditions of remote education in Poland in the period from March 12 to the turn of June and July 2020. 


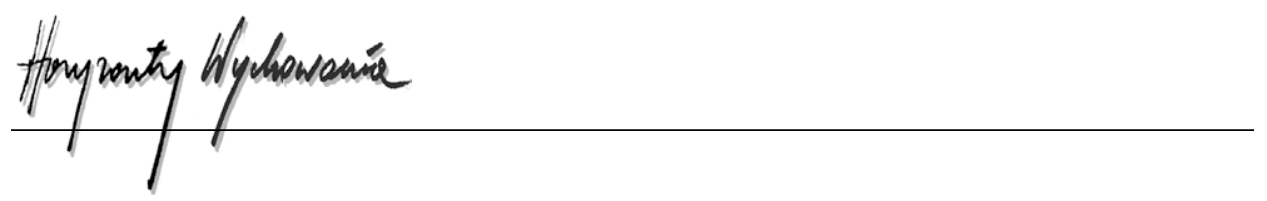

THE RESEARCH PROBLEM AND METHODS: The article was written as part of a pedagogical methodology using a qualitative method that made it possible to analyze the experience of specific people involved in educational processes in the situation of the COVID-19 pandemic.

THE PROCESS OF ARGUMENTATION: The article shows the positive and negative aspects of distance learning from the perspective of family members participating in Poland in an atypical didactic process, forced by the pandemic of a dangerous disease.

RESEARCH RESULTS: The article presents material, competency and interpersonal determinants of remote education.

CONCLUSIONS, INNOVATIONS, AND RECOMMENDATIONS: The research shows that remote education in the conditions of a pandemic had a significant impact on the functioning of families, which requires further research in the situation of a prolonged state of emergency due to COVID-19.

\section{$\rightarrow$ KEYWORDS: COVID-19, PANDEMIC, FAMILY, FAMILY PEDAGOGY, REMOTE EDUCATION}

\section{Wprowadzenie}

Jak wynika z moich wcześniejszych badań, rodzina, której członkiem jest osoba ucząca się, to m.in. instytucja edukacyjna, w której moderowane są i prowadzone różnorodne działania kształceniowe. Wykładniki semantyczne pojęcia kształcenie w rodzinie to, w zależności od epoki lub miejsca funkcjonowania rodziny, przekazywanie wiedzy z zasobów edukacyjnych, które posiadają jej członkowie. Pojęcie kształcenie w rodzinie obejmuje spontaniczne bądź zaplanowane czynności członków rodziny względem siebie, zmierzające do przekazania wiedzy, umiejętności i kompetencji. Wyróżniłam dwa procesy edukacyjne dokonujące się w obrębie rodziny. Pierwszy z nich to podejmowanie działań kształcących w rodzinie w sytuacji, gdy dom rodzinny jest dodatkowym obok przedszkola lub szkoły czy uczelni miejscem kształcenia w ramach edukacji codziennej, prowadzonej zwykle w sposób spontaniczny. Drugi z tych procesów to podejmowanie działań kształcących w stosunku do dzieci w sytuacji, gdy dom rodzinny jest podstawowym miejscem kształcenia, w którym prowadzona jest w sposób zaplanowany edukacja domowa dzieci, zgodnie z regulacjami prawnymi obowiązującymi w danym kraju.

Członkowie rodziny moderują także działania kształceniowe planowane i podejmowane głównie przez dzieci, ale też osoby dorosłe, które chcą rozwijać swoje talenty i umiejętności (Sieradzka-Baziur, 2018, por. też Błasiak, 2019).

Pandemia zakaźnej choroby COVID-19 wywoływanej przez koronawirusa SARSCoV-2, która rozpoczęła się jako epidemia 17 listopada 2019 r. w mieście Wuhan, w prowincji Hubei, w Chinach, i która 11 marca 2020 r. została uznana przez Światową Organizację Zdrowia (WHO) za pandemię, w sposób gwałtowny wpłynęła na funkcjonowanie całego świata, wywierając także znaczący wpływ na szkolnictwo w poszczególnych 
krajach. Zostały zamknięte lotniska, galerie handlowe, liczne zakłady pracy oraz instytucje kształcące dzieci i młodzież. Zgodnie z wytycznymi rządów wielu krajów na świecie, w tym polskiego ${ }^{1}$, wszędzie, gdzie to było możliwe, dom rodzinny uczniów i studentów, dzięki nowoczesnym technologiom informatycznym, stał się podstawowym miejscem ich nauczania w sposób zdalny przez instytucje dydaktyczne. Z kolei ich nauczyciele podjęli pracę w zakresie nauczania swoich podopiecznych, przekształcając swój dom rodzinny w miejsce swojej pracy.

\section{Cel badań i metodologia przyjęta w pracy}

Celem tego artykułu jest ukazanie materialnych, kompetencyjnych i interpersonalnych uwarunkowań kształcenia w rodzinie w Polsce w okresie edukacji zdalnej w warunkach przymusowej izolacji w 2020 r. Został on napisany w ramach metodologii pedagogicznej przy wykorzystaniu metody jakościowej, która umożliwiła analizę doświadczenia konkretnych osób zaangażowanych w procesy edukacyjne w sytuacji pandemii COVID-19. Przedmiotem analizy jest 30 esejów i 30 wywiadów jakościowych z członkami polskich rodzin na temat uwarunkowań kształcenia w rodzinie w dobie COVID-19. Dodatkowy materiał badawczy to kilkadziesiąt doniesień prasowych na temat przebiegu procesów edukacyjnych w rodzinie w trakcie trwania pandemii, które ukazały się od 12 marca do 31 sierpnia 2020 r. w takich polskich czasopismach, jak: „Gazeta Wyborcza”, „Dziennik Polski”, „Tygodnik Powszechny”, „Polityka”, „Wprost”. Przeanalizowałam semantykę wypowiedzi pisemnych (eseje, artykuły prasowe) i ustnych (wywiady jakościowe), biorąc pod uwagę role, które przypadły w udziale członkom rodzin w okresie od 12 marca 2020 r. do czasu powrotu przedszkolaków do przedszkoli w dniu 6 maja, rozpoczęcia wakacji przez uczniów w czerwcu i studentów w połowie lipca tego roku.

Uczestnicy procesów edukacyjnych funkcjonowali w obrębie takich ról jak:

1. Ja jako uczeń/ Ja jako student.

2. Ja jako uczący (nauczyciel w przedszkolu, nauczyciel w szkole, nauczyciel akademicki).

3. Ja jako osoba wspierająca, obserwująca kształcenie się członków rodziny w domu i kształcenie przez członków rodziny w domu (ja jako matka, ojciec, syn, córka, dziadek, babcia, brat, siostra etc.).

\footnotetext{
${ }^{1}$ Zgodnie z rozporządzeniami Ministra Edukacji Narodowej oraz Ministra Nauki i Szkolnictwa Wyższego z dnia 11.03.2020 roku od dnia 12.03.2020 do rozpoczęcia wakacji w czerwcu 2020 roku nie odbywały się tradycyjne zajęcia w polskich szkołach i uczelniach wyższych, por. Rozporządzenie Ministra Edukacji Narodowej z dnia 11 marca 2020 r. w sprawie czasowego ograniczenia funkcjonowania jednostek systemu oświaty w związku z zapobieganiem, przeciwdziałaniem i zwalczaniem COVID-19; Rozporządzenie Ministra Nauki i Szkolnictwa Wyższego z dnia 11 marca 2020 r. w sprawie czasowego ograniczenia funkcjonowania niektórych podmiotów systemu szkolnictwa wyższego i nauki. Przedszkola zostały otwarte 6 maja 2020 r., por. https://www.gov.pl/web/ edukacja/otwieramy-przedszkola-od-6-maja (dostęp: 09.09.2020).
} 


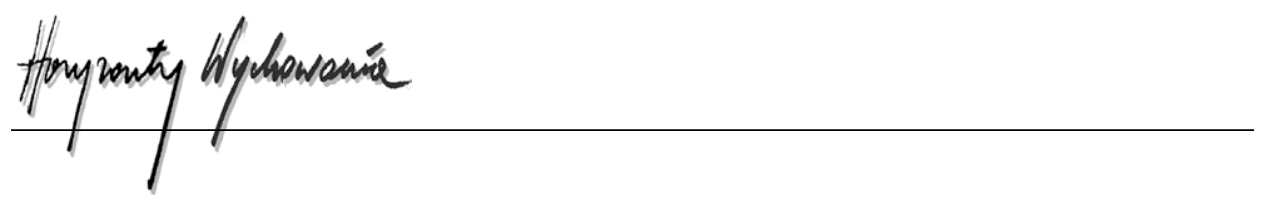

W trakcie kształcenia zdalnego członkowie rodzin występowali w jednej z wymienionych powyżej ról, w dwóch rolach albo w trzech (1) (2) (3). Analizie poddałam 10 esejów napisanych przez uczniów, 10 przez studentów i 10 przez rodziców (5 spośród nich to nauczyciele), oraz 10 wywiadów jakościowych udzielonych przez uczniów, 10 przez studentów, 10 przez rodziców (5 spośród nich to nauczyciele). Autorzy esejów zostali poproszeni o stworzenie osobistego, szczerego opisu tego, czego doświadczali w dobie koronawirusa, pełniąc zróżnicowane role w zależności od swojej sytuacji życiowej. Pytania wywiadu dotyczyły uwarunkowań materialnych, kompetencyjnych i interpersonalnych edukacji zdalnej prowadzonej w domu rodzinnym.

\section{Materialne uwarunkowania edukacji zdalnej}

Fizyczne zamknięcie instytucji edukacyjnych takich jak przedszkola, szkoły i uczelnie w Polsce nie oznaczało przerwania procesów edukacyjnych. W mocy zostały utrzymane ministerialne rozporządzenia zawierające wymogi odnoszące się do edukowania dzieci i młodzieży² oraz sylabusy do przedmiotów prowadzonych na uczelniach wyższych. W sytuacji zagrożenia chorobą COVID-19 na terenie całego kraju podjęto nauczanie zdalne (określane też synonimicznie jako kształcenie na odległość, e-learning, e-edukacja, cyfrowa edukacja, kształcenie cyfrowe), prowadzone przy wykorzystaniu komputerów i sieci informatycznej ${ }^{3}$. Technologie informacyjno-komunikacyjne umożliwiły organizację procesu edukacyjnego, którego treścią są:

- podmioty kształcenia (uczeń, student, nauczyciel);

- przedmiot kształcenia oraz zasoby konieczne do jego prowadzenia;

- środowisko dydaktyczno-wychowawcze (przedszkole, szkoła, uczelnia, instytucja opiekuńcza, dom rodzinny, środowisko rówieśnicze).

Aby w warunkach przymusowego odosobnienia efektywnie uczestniczyć w procesach edukacyjnych zachodzących przy wykorzystaniu technologii cyfrowych, konieczne się stało posiadanie w domu przez nauczyciela i ucznia:

- komputera o wysokich parametrach technicznych wyposażonego w kamerę wideo oraz mikrofon i głośniki, a także opcjonalnie smartfona, tabletu i niejednokrotnie także drukarki, skanera;

\footnotetext{
${ }^{2}$ Podstawy programowe dla przedszkoli, podstawy programowe dla szkół podstawowych, podstawy programowe dla szkół średnich znajdują się na platformie edukacyjnej Ministerstwa Edukacji Narodowej https://epodreczniki.pl (dostęp: 08.09.2020).

${ }^{3} \mathrm{~W}$ ograniczonym zakresie nauka odbywała się także przy wykorzystaniu telewizji polskiej. Programy dydaktyczne w ramach cyklu „Szkoła z TVP” były emitowane w okresie pandemii od marca, od poniedziałku do piątku na ogólnodostępnych antenach Telewizji Polskiej. Znalazły się także na VOD.TVP.PL. Program „Szkoła z TVP” został skierowany do nauczycieli, dyrektorów, młodszych i starszych uczniów, a także rodziców. W ramach akcji na antenach TVP były emitowane materiały dostosowane do podstawy programowej szkół podstawowych. Można je było obejrzeć na czterech kanałach: TVP3, TVP Rozrywka, TVP Sport oraz TVP Historia.
} 
- dostępu do wystarczająco szybkiego łącza internetowego;

- oprogramowania umożliwiającego korzystanie z platformy do zdalnej edukacji;

- odpowiednich warunków lokalowych w kontekście relacji rodzinnych.

Jak wynika z opinii respondentów, doniesień prasowych i własnych doświadczeń dydaktycznych autora tego artykułu, część uczniowskich, a nawet nauczycielskich rodzin jest w jakimś stopniu lub całkowicie cyfrowo wykluczona - z powodu braku wymienionych powyżej sprzętów, programów, dostępu do Internetu i odpowiednich warunków lokalowych. Skala tego zjawiska - z podziałem na cztery wymienione powyżej kategorie - jest trudna do dokładnego oszacowania. Na podstawie dostępnych danych można stwierdzić, że zjawisko to w różnym natężeniu dotyka kilku do kilkunastu procent polskich rodzin. W omawianym okresie uwidocznił się proces przyspieszonej cyfryzacji w rodzinach: zakupy sprzętu elektronicznego i przyłączanie do sieci internetowej. Materialnym uwarunkowaniem edukacji zdalnej są także zasoby edukacyjne konieczne do jej prowadzenia. Zagrożenie związane z pandemią oznaczało w Polsce także zamknięcie bibliotek, co szczególnie w przypadku młodzieży studiującej negatywnie wpłynęło na jej możliwości pozyskiwania wiedzy. Zasoby edukacyjne istotne w trakcie edukacji zdalnej to $m$.in. podręczniki oraz książki i inne materiały dydaktyczne w wersji papierowej i cyfrowej, dostępne w zasobach rodzinnych. Inne zasoby edukacyjne dostępne uczącym się i nauczającym to nieprzebrane dydaktyczne zasoby Internetu (biblioteki cyfrowe, audioteki, muzea cyfrowe, gry sieciowe etc.) i strony do tworzenia aplikacji edukacyjnych, np. LearningAps ${ }^{4}$.

Jak wynika z przeprowadzonych przeze mnie badań jakościowych, w analizowanym okresie w Polsce były używane zróżnicowane narzędzia do edukacji zdalnej. Nauczyciele w swojej praktyce dydaktycznej korzystali z narzędzi cyfrowych, takich jak np. platformy e-learningowe Moodle oraz Microsoft Teams, a także takich komunikatorów, jak np. Zoom, Skype, Messenger, WhatsApp. Narzędzia te dawały możliwość kontaktu wzrokowego i słuchowego z uczącymi się, jednak z praktyki dydaktycznej wynika, że ograniczenia sprzętowe i związane z dostępnością do Internetu niejednokrotnie obniżały jakość tego kontaktu, a nawet go uniemożliwiały. W celu prowadzenia edukacji zdalnej nauczyciele, uczniowie i studenci korzystali także z możliwości kontaktu słuchowego poprzez telefony komórkowe oraz pisemnego przy wykorzystaniu poczty elektronicznej, e-dzienników, portali społecznościowych (Facebook, Twitter, Snapchat), forów internetowych, czatów. Dodać też należy, że w trakcie edukacji zdalnej w dużym zakresie wykorzystywane były smartfony, które stanowiły znaczne wsparcie dla tej formy edukacji.

Podsumowując ustalenia na temat materialnych uwarunkowań edukacji zdalnej prowadzonej w polskich domach w warunkach pandemii, należy zadać następujące pytanie:

\footnotetext{
${ }^{4}$ Ministerstwo Edukacji Narodowej wydało publikację: Kształcenie na odległość - poradnik dla szkół, w którym podało, jak należy kształcić w warunkach pandemii, co należy do obowiązków dyrektorów i nauczycieli, jak realizować podstawę programową w warunkach domowych, jak zwiększyć efektywność zdalnej nauki, w jaki sposób zaplanować czas dziecka w domu oraz z jakich narzędzi i materiałów korzystać, por. https://www.gov.pl/web/edukacja/ksztalcenie-na-odleglosc--poradnik-dla-szkol (dostęp: 08.09.2020).
} 


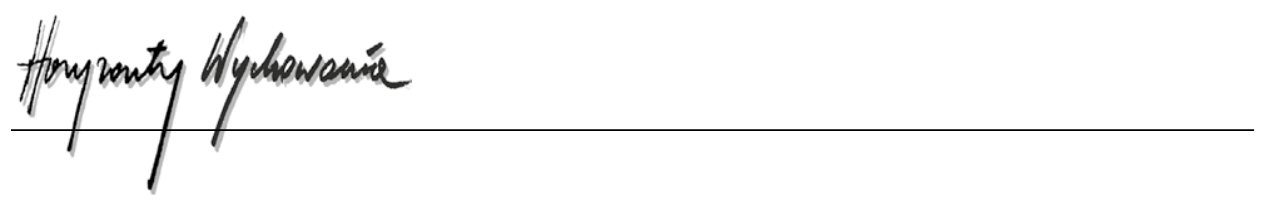

„Jak to się stało, że mimo zagrożenia chorobą, która sparaliżowała cały kraj, przedszkolne, szkolne i uniwersyteckie nauczanie było regularnie prowadzone i od marca do maja/ czerwca/ lipca 2020 odbywały się lekcje, wykłady, seminaria, ćwiczenia, konwersatoria, uczniowie zdawali egzaminy końcowe, odbyły się matury, studenci i doktoranci bronili swoich prac magisterskich i doktorskich"?

Odpowiedź na to pytanie jest bardzo prosta:

„Edukacja była kontynuowana, bo było to możliwe”.

Rozwój technologiczny w zakresie komunikowania się na odległość, nieprzebrane zasoby Internetu oraz sprzęt elektroniczny w domach uczniów, studentów i nauczycieli sprawiły, że procesy edukacyjne istotne z punktu widzenia rozwoju społeczeństwa i pojedynczych osób mogły być w warunkach pandemii kontynuowane w zasadzie na terenie całego kraju. Należy docenić to dobrodziejstwo mimo trudności, mankamentów i ewidentnych nierówności ze względu na cyfrowe wykluczenie, jakiego doświadcza część uczniów i nauczycieli na świecie i w Polsce ${ }^{5}$.

\section{Kompetencyjne uwarunkowania edukacji zdalnej}

Kompetencje cyfrowe nauczycieli, a także uczniów, studentów i ich rodziców oraz innych członków rodzin zaangażowanych w edukację zdalną, niezbędne w procesie uczestnictwa w e-learningu, są zróżnicowane. Znaczna część współczesnej kadry dydaktycznej w Polsce to osoby, które nie uczestniczyły w regularnym, formalnym procesie kształcenia z zakresu informatyki, a znajomość obsługi komputera i Internetu uzyskały dzięki kursom lub korzystając z pomocy młodszych kolegów czy członków rodziny. W okresie pandemii kadra nauczająca w szkołach i na uczelniach uczestniczyła w przyspieszonych kursach z zakresu obsługi platform e-learningowych i innych dostępnych form edukacji na odległość. Młodsze pokolenia - uczniowie i studenci - brały już udział w zajęciach z zakresu informatyki w szkołach i na uczelniach wyższych, więc ich kompetencje cyfrowe są zwykle znacznie większe aniżeli kompetencje ich nauczycieli czy rodziców. Nierówności kompetencyjne w zakresie znajomości nowych technologii edukacyjnych nie uniemożliwiły jednak prowadzenia kształcenia zdalnego w dobie pandemii COVID-19, jednak w znaczący sposób decydowały o jej jakości.

\footnotetext{
${ }^{5}$ António Guterres, sekretarz generalny ONZ mówi: „The COVID-19 pandemic has led to the largest disruption of education ever. In mid-July, schools were closed in more than 160 countries, affecting over 1 billion students. At least 40 million children worldwide have missed out on education in their critical pre-school year. And parents, especially women, have been forced to assume heavy care burdens in the home. Despite the delivery of lessons by radio, television and online, and the best efforts of teachers and parents, many students remain out of reach. Learners with disabilities, those in minority or disadvantaged communities, displaced and refugee students and those in remote areas are at highest risk of being left behind. Pozyskano z: https://www.un.org/en/ coronavirus/future-education-here (dostęp: 08.09.2020).
} 
Nauka zdalna przyjęła w trakcie przymusowego odosobnienia dwie zasadnicze formy:

1. Nauczyciel przesyłał przez pocztę elektroniczną, platformy edukacyjne, Facebooka, e-dziennik etc. materiały dydaktyczne w postaci plików, następnie przesyłał zadania sprawdzające przyswojenie materiału dydaktycznego, uczący się wykonywali zadania, przesyłali je uczącemu, po czym nauczyciel poddawał je ocenie. Prowadzący zajęcia zdalne odsyłał też uczniów do ich podręczników czy skryptów, zlecał lekturę określonych fragmentów tych pomocy dydaktycznych, wdrażał system zadań i poddawał te zadania ocenie. Zajęcia były prowadzone także w formie wykładów online, często w połączeniu z prezentacją multimedialną. Taka forma prowadzenia zajęć zdalnych powiela tradycyjny, transmisyjny model procesu edukacyjnego, realizowanego w trybie podającym.

Respondenci wyrażają przekonanie, że to często głównie brak wiedzy z zakresu IT jest w przypadku nauczycieli przyczyną tego, że zamiast wykorzystywać metody aktywizujące, wybierają podający tryb nauczania i wysyłają duże ilości materiałów w postaci plików tekstowych. Materialnym rezultatem tak pojętej edukacji zdalnej są zapełnione plikami komputery uczących się lub plaftormy edukacyjne, które mimo rozbudowanej funkcjonalności są wykorzystywane w sposób częściowy, gdyż niejednokrotnie pełnią prawie wyłącznie rolę repozytoriów plików. Magazynuje się w nich pliki (artykuły naukowe, skrypty, książki naukowe, książki do nauki języków, instruktaże do ćwiczeń, recenzje etc.), gdy tymczasem były pomyślane jako żywe środowisko wspomagające uczenie się (Tomczyk, 2020).

2. Praca zdalna oparta na metodzie projektów, z wykorzystaniem poczty elektronicznej, platform edukacyjnych, Facebooka, e-dziennika czy materiałów podręcznych realizowana w formie webinariów, seminariów, zajęć konwersatoryjnych, ćwiczeniowych. Ten typ zajęć zdalnych inspirowany jest metodą WebQuest i był realizowany w praktyce głównie w pracy ze studentami i starszymi uczniami. Wykorzystując funkcjonalności platformy edukacyjnej, nauczyciel omawiał zadanie projektowe i wyznaczał w trakcie wspólnych zajęć osoby, którym zostały te zadania przydzielone. Przekazywał linki do źródeł informacji w zasobach internetowych i materiały dydaktyczne w postaci plików. Uczniowie lub studenci realizowali projekty indywidualne lub grupowe, a ich wyniki zamieszczali na platformie, a następnie prezentowali w trakcie zajęć (webinariów). Nauczyciel wysłuchiwał relacji poszczególnych osób, podsumowywał je, systematyzował wiedzę i poddawał projekty ocenie zgodnie z kryteriami zamieszczonymi na platformie.

W taki sposób prowadzona edukacja zdalna wykorzystywała metody aktywizujące wychowanków. W jej trakcie tworzone i wykorzystywane były interaktywne quizy, gry internetowe, filmy nagrane przez uczniów, studentów i nauczycieli, ankiety interaktywne, zdjęcia, plakaty, projekty graficzne, otwarte blogi, pliki tekstowe dotyczące danego zagadnienia. 


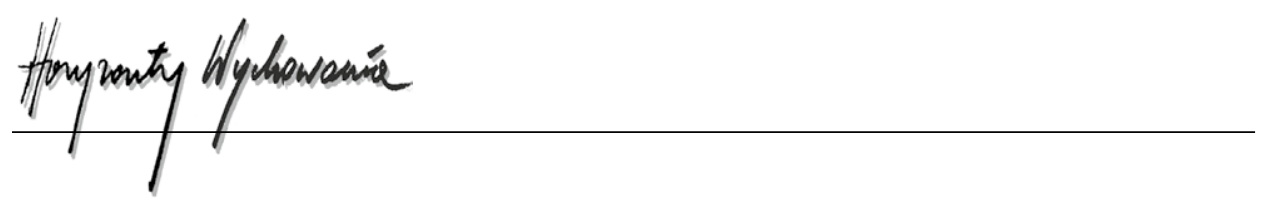

\section{Interpersonalne uwarunkowania edukacji zdalnej}

Jedną z najistotniejszych potrzeb istoty ludzkiej, warunkiem niezbędnym do jej prawidłowego funkcjonowania, jest relacja z innymi ludźmi, ich bezpośrednia fizyczna obecność. Zdalne nauczanie zmieniło drastycznie możliwości w zakresie budowania bezpośrednich relacji, stąd w dobie zagrożenia koronawirusem kluczowe stało się pytanie dotyczące tego, jak w sytuacji przymusowej izolacji zachowywać, podtrzymywać i ulepszać relacje międzyludzkie.

Przed wybuchem pandemii relacje interpersonalne w zakresie kształcenia osób uczących się i nauczających - przedstawiały się następująco:

1. relacja uczeń/student $\leftrightarrow$ rodzic (lub/i inny członek rodziny) w zakresie pomocy w nauce, organizacji nauki w domu, moderowania procesów edukacyjnych;

2. relacja uczeń/student $\leftrightarrow$ nauczyciel;

3. relacja uczeń $\leftrightarrow$ uczeń, student $\leftrightarrow$ student - w szkole/na uczelni;

4. relacja nauczyciel $\leftrightarrow$ rodzic (opiekun) ucznia szkoły podstawowej lub średniej.

W sytuacji pandemii, $w$ trakcie kontynowania procesów edukacyjnych w formie zdalnej relacje te zachodziły między tymi samymi osobami, zmieniła się jednak w pewnym zakresie ich forma - ze względu na to, że procesy kształcenia i zdobywania wiedzy odbywały się w domach podmiotów tych relacji. Matki, macochy, ojcowie, ojczymi, córki, synowie, bracia, siostry, dziadkowie i inni członkowie rodziny ukryli się przed niebezpieczeństwem pandemii w swoich domach i relacje, które zbudowali przed jej wybuchem, miały istotny wpływ na ich funkcjonowanie w nowej rzeczywistości oraz efektywność edukacji zdalnej. Relacje te uzależnione są w znaczącym stopniu od tego, w jakim typie rodziny żyją jej członkowie. Efektywność edukacji zdalnej była uzależniona także od warunków lokalowych i od tego, ile osób przebywało w domu w trakcie jej trwania, ile osób w niej uczestniczyło w charakterze uczniów, studentów czy nauczycieli, a ilu członków rodziny wykonywało w domu prace zdalne, niezwiązane z dydaktyką. W momencie zamknięcia przedszkoli, szkół i uczelni na początku epidemii członkowie polskich rodzin doświadczali ambiwalentnych uczuć. Niepokój i lęk o przyszłość związany z doświadczeniem czegoś nagłego, zaskakującego na początku współwystępował z radością, gdyż zamknięcie przedszkoli, szkół i uczelni oznaczało czas wolny od obowiązków związanych z uczeniem się i nauczaniem. Fizyczne zamknięcie instytucji edukacyjnych nie oznaczało jednak przerwania edukacji, w mocy zostały utrzymane ministerialne rozporządzenia zawierające wymogi odnoszące się do edukowania dzieci i młodzieży oraz sylabusy do przedmiotów prowadzonych na uczelniach wyższych opracowane przez prowadzących zajęcia. Wymogi pozostały niezmienione, natomiast diametralnie zmieniły się warunki i możliwości odnoszące się do ich realizacji. Dzieci przedszkolne, uczniowie, nauczyciele i rodzice znaleźli się w sytuacji kryzysu, gdyż napotkali przeszkody uniemożliwiające realizacje życiowych celów, czego rezultatem stało się niejednokrotnie doświadczanie silnych negatywnych emocji związanych m.in. z odmiennym typem komunikowania się w sytuacji pandemii. Uczniowie i studenci nie spotykali się ze swoim nauczycielem i rówieśnikami twarzą w twarz w tym samym pomieszczeniu, a kontakt 
umożliwiało im dostępne narzędzie elektroniczne (komputer, smartfon, tablet). Ten typ komunikacji określa się mianem zapośredniczonej ze względu na użycie „pośrednika” w postaci narzędzia elektronicznego (Bollinger, 2009).

Komunikacja zapośredniczona elektronicznie ma dwie postaci:

1. ustna komunikacja zapośredniczona,

2. pisemna komunikacja zapośredniczona.

Komunikacja twarzą w twarz odbywająca się w tym samym pomieszczeniu to komunikacja wizualna, audialna, bezpośrednia - w odróżnieniu od wizualnej, audialnej, pośredniej (zapośredniczonej elektronicznie), w trakcie której uczestnicy mogą się widzieć i słyszeć dzięki narzędziom elektronicznym, przebywając w innych miejscach. Portale e-learningowe typu Moodle, Microsoft Teams, a także Zoom, Skype, Messenger umożliwiają komunikację wizualną i audialną, która stanowi najbogatszą formę kontaktu społecznego w dobie przymusowej izolacji, zapewniając synchroniczny kontakt (w czasie rzeczywistym), który może zostać dodatkowo wzbogacony o komunikację pisemną w formie czatu czy e-maila. Z moich badań wynika, że uczestnicy komunikacji zapośredniczonej wizualnej i audialnej doceniają tę formę kontaktu ucznia, studenta z nauczycielem w ramach lekcji szkolnych czy zajęć na uczelni, w obrębie grupy rówieśniczej - z uwagi na korzyści dydaktyczne i socjalizujące. Dzięki tej formie w czasie przymusowej izolacji uczący się i nauczyciele mogą zapewniać sobie w jakimś stopniu realizację potrzeby przynależności i potrzeby poznawczej. Zapośredniczona elektronicznie wizualna i audialna komunikacja synchroniczna jest też użyteczna w relacjach nauczycieli z rodzicami oraz w grupach rówieśniczych uczniów i studentów. Uwarunkowania materialne omówione w poprzedniej części artykułu niejednokrotnie uniemożliwiają ten typ komunikacji. Z drugiej jednak strony niektórzy uczestnicy edukacji zdalnej z różnych powodów (psychologicznych lub ze względu na uwarunkowania społeczne) unikali kontaktu wizualnego lub/i audialnego, chociaż mieli takie możliwości materialne.

Edukacja zdalna sprzyjała socjalizacji osób zamkniętych w rodzinnych domach. Uczniowie i studenci podkreślali w swoich esejach i wywiadach rolę wsparcia, jakiego niejednokrotnie udzielali im nauczyciele, którzy w trakcie zapośredniczonego komunikowania się kierowali do nich słowa otuchy i pocieszenia. W tym celu nauczyciele wykorzystywali teksty filozoficzne, religijne - niejednokrotnie o uniwersalnej wymowie, fragmenty literatury, reprodukcje dzieł sztuki. Mając świadomość, że jedną z najbardziej istotnych umiejętności, których człowiek potrzebuje, aby poradzić sobie z kryzysem, jest umiejętność rozmawiania, starali się pomóc uczniom nazwać, opisać i wyrazić uczucia, których doświadczali. Niektórzy z nauczycieli zachęcali swoich wychowanków do tworzenia memów, gifów, anegdot, żartów, snapów, kalamburów etc. Relacja uczeń/student $\leftrightarrow$ nauczyciel nie sprowadzała się tylko do przekazywania wiedzy, ale oznaczała też niejednokrotnie pozytywną, wspierającą więź człowieka z człowiekiem.

W okresie przymusowej izolacji wielkie znaczenie miało także nawiązanie i kontynuowanie w zmienionych warunkach relacji nauczyciel $\leftrightarrow$ rodzic (opiekun) ucznia szkoły podstawowej lub średniej. 


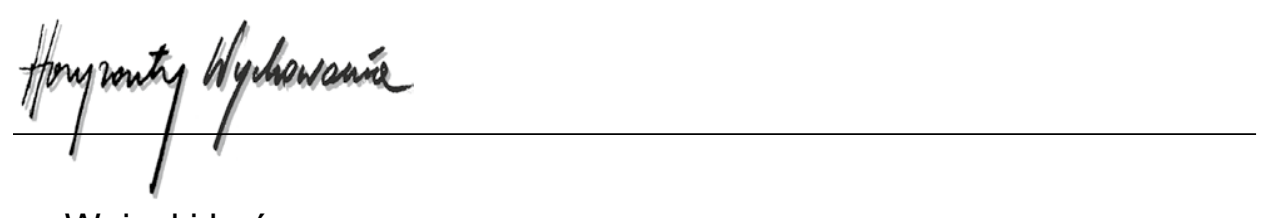

\section{Wnioski końcowe}

Rodzina jako środowisko wychowawcze, opiekuńcze i kształcące w trakcie pandemii koronawirusa została postawiona wobec zadań, których dotąd nigdy w takim zakresie nie pełniła. W dobie COVID-19 zgodnie z rozporządzeniami władz państwowych wprowadzone zostało nauczanie zdalne, które trwało od marca do maja w przypadku przedszkolaków, a w przypadku uczniów i studentów odpowiednio - do końca czerwca lub połowy lipca 2020 r. Zajęcia przedszkolne, szkolne i uniwersyteckie prowadzone były w domach uczniów, a dla nauczycieli dom stał się ich miejscem pracy. W dalszym ciągu prowadzona była edukacja domowa zgodnie z przepisami polskiego prawa. Jak wynika z przeprowadzonych badań jakościowych, rezultaty edukacji zdalnej uzależnione były od czynników materialnych, kompetencyjnych uczniów i nauczycieli oraz relacji interpersonalnych podmiotów edukacji oraz rodziców w trakcie jej trwania. Uczniowie ukończyli kolejny rok szkolny, ósmoklasiści stosownie do rezultatów egzaminów końcowych zostali przyjęci do szkół średnich, a maturzyści na podstawie wyników matury będącej podstawą starań o przyjęcia na studia zostali studentami wyższych uczelni.

Trudna sytuacja pandemii i wymuszonego przez nią zdalnego nauczania przyniosła pozytywne wyniki, do których należy zaliczyć:

1. Wzrost kompetencji cyfrowych i pogłębioną refleksję nad dalszymi kierunkami rozwoju zdalnej edukacji w Polsce.

2. Zwiększoną transmisję wiedzy i umiejętności w relacjach interpersonalnych w odniesieniu do technologii informacyjno-komunikacyjnych.

3. Rozbudowę infrastruktury informatycznej.

4. Wyposażenie niektórych uczniów i studentów w konieczny sprzęt elektroniczny.

5. Rozwój firm i instytucji zajmujących się zdalnym nauczaniem.

W sposób nieunikniony pojawia się teraz następujące pytanie: „Skoro przedszkola, szkoły i uczelnie wyższe mogą funkcjonować w sposób zdalny, to z jakiego powodu obserwujemy niemalże powszechne pragnienie powrotu do tradycyjnego nauczania?". Jak się okazuje, realizacja nauczania na odległość okupiona była bardzo wysokimi kosztami społecznymi i emocjonalnymi. Istnieje bardzo wiele czynników, które się na to składają, o czym świadczą też wyniki przeprowadzonych przeze mnie badań.

1. Nauczanie zdalne prowadzone jako je dy ny typ nauczania nie zaspokaja potrzeby przynależności, należącej do kluczowych potrzeb istoty ludzkiej.

2. Metody i środki edukacji zdalnej są dopiero w trakcie tworzenia.

3. Niektórzy uczestnicy edukacji zdalnej doświadczali wykluczenia cyfrowego

4. Zgodnie z opiniami badanych, ograniczenia zdalnej edukacji negatywnie wpłynęły na poziom zdobytej wiedzy

5. Funkcjonowanie w zamkniętych przestrzeniach w sytuacji zagrożenia wpłynęło negatywnie na poziom zdrowia fizycznego i psychicznego wielu uczniów i nauczycieli.

6. Została zaburzona równowaga między pracą i nauką a życiem prywatnym. 


\section{BIBLIOGRAFIA}

Błasiak, A. (2019). Tendencje zmian we współczesnych rodzinach w ponowoczesności. Horyzonty Wychowania, vol. 18 , no. $45,11-21$.

Bollinger, D.U. (2009). Use patterns of visual cues in computer-mediated communication. Review of Distance Education, 2, 95-108.

Sieradzka-Baziur, B. (2018). Kształcenie w rodzinie w świetle terminów pedagogicznych. W: B. Sieradzka-Baziur (red.), Pedagogika rodziny na początku XXI wieku w świetle pojęć i terminów. Kraków: Wydawnictwo Naukowe Akademii Ignatianum w Krakowie.

Tomczyk, Ł. (2020). Czego możemy nauczyć się od tych, którzy prowadzą zdalną edukację od dawna. W: J. Pyżalski (red.), Edukacja w czasach pandemii wirusa COVID-19. Z dystansem o tym, co robimy obecnie jako nauczyciele, s. 93-97. Pozyskano z: https://zdalnie.edu-akcja. pl/ (dostęp: 08.09.2020).

\section{Copyright and License}

This article is published under the terms of the Creative Commons Attribution - NoDerivs (CC BY- ND 4.0) License http://creativecommons.org/licenses/by-nd/4.0/ 